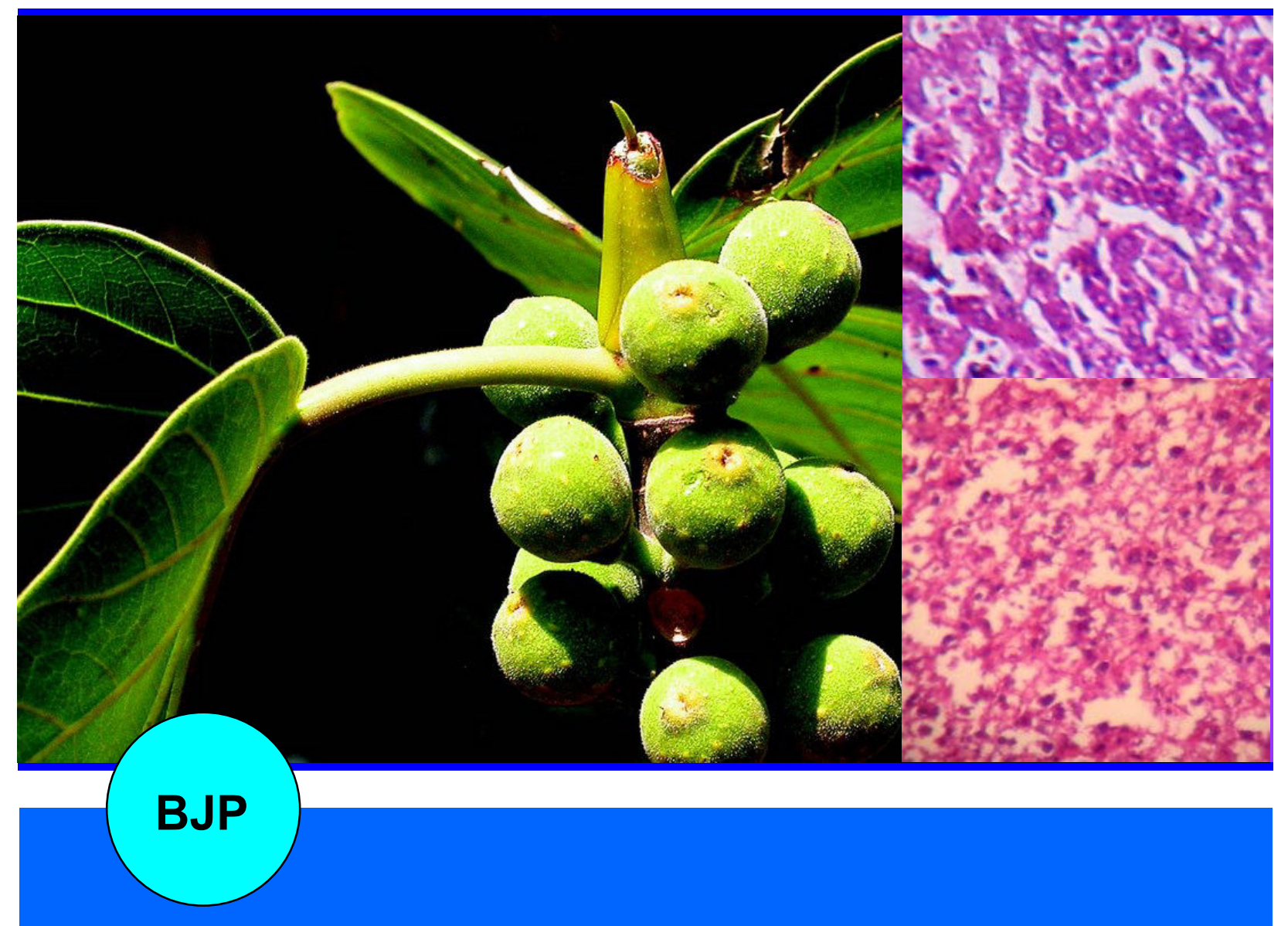

Bangladesh Journal of Pharmacology

Research Article

Amelioration of carbon tetrachloride - and paracetamol-induced hepatotoxicity in rats by Ficus dalhousiae 


\title{
Amelioration of carbon tetrachloride- and paracetamol-induced hepatotoxicity in rats by Ficus dalhousiae
}

\author{
Syed Safiullah Ghori',3, Mohib Khan² and Shaikh Abdul Rahman3 \\ ${ }^{1}$ Department of Pharmacology, Himalayan University, Naharlagun, Itanagar, Arunachal Pradesh, India; ${ }^{2}$ Department \\ of Pharmacognosy and Phytochemistry, Oriental College of Pharmacy, Sanpada (E), Navi Mumbai, India; \\ ${ }^{3}$ Department of Pharmacology \& Pharmaceutical Chemistry, Anwarul Uloom College of Pharmacy, New Mallepally, \\ Hyderabad 500001, Andhra Pradesh, India.
}

\begin{tabular}{|c|c|}
\hline Article Info & \\
\hline Received: & 22 September 2014 \\
\hline Accepted: & 7 October 2014 \\
\hline Available Online: & 18 November 2014 \\
\hline DOI: $10.3329 /$ bjp.v & 9i4.20515 \\
\hline $\begin{array}{l}\text { Cite this article: } \\
\text { Ghori SS, Khan M, } \\
\text { lioration of carbor } \\
\text { paracetamol- ind } \\
\text { in rats by F } \\
\text { Bangladesh J Phar }\end{array}$ & $\begin{array}{l}\text { Rahman SA. Ame- } \\
\text { tetrachloride- and } \\
\text { aced hepatotoxicity } \\
\text { icus dalhousiae. } \\
\text { macol. 2014; 9: 588- }\end{array}$ \\
\hline
\end{tabular}

\begin{abstract}
The present study was undertaken to investigate hepatoprotective activity of Ficus dalhousiae leaves ethanolic extract based on its traditional claim. Paracetamol- and carbon tetrachloride-induced hepatotoxicity in albino Wistar rats, experimental models was used for the evaluation. Various biochemical parameters like SGPT, SGOT, serum albumin, alkaline phosphatase, total bilirubin, direct bilirubin and total protein were estimated. Oral treatment with the extract 250 and $500 \mathrm{mg} / \mathrm{kg}$, significantly $(\mathrm{p}<0.01)$ altered all the serum marker levels to the normal in both the experimental models. The activity of the extract was comparable to that of standard drug, silymarin $(25 \mathrm{mg} / \mathrm{kg}$, p.o.). Histopathological observations also demonstrated protective effect of the test extract on liver anatomy. Overall results suggest
\end{abstract}

\section{Introduction}

The liver is a vital organ present in vertebrates and in some other animals. It has wide range of functions, including detoxification, protein synthesis, and production of biochemicals necessary for digestion. Liver has a pivotal role in regulation of physiological processes. It is involved in several vital functions such as metabolism, secretion and storage. Further, detoxification of a variety of drugs and xenobiotics occurs in the liver itself. A healthy liver is a sign of good health (Subramonium and Pushpangadan, 1999). The bile secreted by the liver has an important role in digestion. Liver diseases are among the most serious disorders. They may be classified as acute or chronic hepatitis (inflammatory liver diseases), hepatosis (noninflammatory diseases) and cirrhosis (degenerative disorder resulting in fibrosis of the liver). The liver diseases are mainly caused by toxic chemicals (certain antibiotics, chemotherapeutics, peroxidised oils, aflatoxins, carbon tetrachloride, acetaminophen, chlorinated hydrocar- bons, etc.), excess consumption of alcohol, infections and autoimmune disorders

Most of the hepatotoxic chemicals damage liver cells mainly by inducing lipid peroxidation and by oxidative damage. Liver disease is still a worldwide health problem. Many synthetic drugs are used in the treatment of liver diseases but unfortunately have serious side effects (Guntupalli et al., 2006). In the absence of a reliable liver protective drug in modern medicine there are a number of medicinal preparations in Ayurveda recommended for the treatment of liver disorders. In view of severe undesirable side effects of synthetic agents, there is growing focus to follow systemic research methodology and to evaluate scientific basis for the traditional herbal medicines that are claimed to possess hepatoprotective activity. Almost $80 \%$ people all over the world depend on traditional medicine to cure their major and minor ailments (Mallhi et al., 2014). Natural plants have a very important role in treatment of liver diseases (Alamgeer 
et al., 2014). Many plants have been identified as hepatoprotective like Trianthema decandra (Balamuruganvelu, 2014), Carica papaya (Sadeaque 2010), Convulus arvensis (Ali et al., 2013), Khamira Gaozaban Ambri Jadwar Ood Saleeb Wala (Akhtar et al., 2013). Liver damage is associated with cellular necrosis, increase in tissue lipid peroxidation and depletion in the GSH levels in addition to increase in serum levels of many biochemical markers like SGOT, SGPT, triglycerides, cholesterol, bilirubin, alkaline phosphate etc. The leaves and bark of Ficus dalhousiae which belongs to the family Moraceae are recommended for treatment of ailments of liver and skin diseases. Fruit is used as cardiotonic (Khare, 2007).

\section{Material and Methods}

Plant material: Plant material was collected from Tirupati A.P, during the month of Dec. 2011. Authentication of plant material was done in Department of Botany, Osmania University, Hyderabad -500 007. India, S. No. 112, Voucher No. 0949. Freshly collected plant material was used for the present study.

Chemicals: All the chemicals were of analytical grade. Carbon tetrachloride and paracetamol were obtained from drug Store, Anwarul Uloom College of Pharmacy. Silymarin as gift sample from Ranbaxy Laboratories was used as standard drug.

Preparation of extract: The collected leaves were washed thoroughly under running water and air dried for eight days. Then the dried leaves were coarsely powdered using grinder and were continuously extracted in a soxhlet apparatus by different solvents in the increasing order of polarity. The extracts were filtered through a filter paper (Whatman, No. 1) and evaporated under reduced pressure in a rotary evaporator. The obtained extracts were stored in amber colored glass bottles for further processing (Deore et al., 2014). As the yield of the ethanolic extract was more compared with others, this extract was used for the assessment of hepatoprotective activity.

Phytochemical analysis: The percentage yield of the different extracts was as follows: n-hexane- $5.2 \%$; ethylacetate- $6.4 \%$; chloroform- $5.2 \%$; ethanol- $8.6 \%$; distilled water- $6.2 \%$. Phytochemical screening of the extracts was performed by simple qualitative methods (Khandelwal, 2000).

Experimental animals: Healthy Wistar albino rats weighing about (120-160 g) of either sex were obtained from the animal house. The animals were maintained under standard conditions i.e., housed in polypropylene cages and maintained at a temperature $27 \pm 2{ }^{\circ} \mathrm{C}$, relative humidity $65 \pm 10 \%$ under 12 hours light and dark cycle. The animals were acclimatized for 10 days under laboratory conditions before carrying out the experiments. The animals were housed in the animal house approved by the Committee for the Purpose of control and supervision of experimental animals (CPCSEA)Registration number - 1534/PO/A/11/CPCSEA.

Acute toxicity studies: Acute oral toxicity study was performed as per OECD-423 guidelines category IV (acute toxic class method,). Albino mice $(n=3)$ of either sex selected by random sampling technique were employed in this study. The animals were kept fasting for 4 hours with free access to water only. The plant extract was administered orally with maximum dose of $2,000 \mathrm{mg} / \mathrm{kg}$ body weight by gastric intubation. The mortality was observed for three days. If mortality was observed in 2 out of 3 animals or 3 out of 3 animals then the dose administered was assigned as toxic dose. If mortality was observed in 1 animal, then the same dose was repeated again to confirm the toxic dose. If mortality was not observed, the procedure was repeated for further higher dose such as $3,000 \mathrm{mg} / \mathrm{kg}$ of body weight (OECD 2006). There was no mortality shown up to a dose of 2,000 mg/ $\mathrm{kg}$ of ethanolic extract.

Histopathological studies: Sections were taken immediately from the liver, fixed in $10 \%$ formalin, dehydrated in gradual ethanol $(50-100 \% \mathrm{v} / \mathrm{v})$, cleared in xylene and embedded in paraffin. Sections (4-5 $\mu \mathrm{m}$ thick) were prepared and then stained with hematoxylin and eosin (H-E) dyes for photomicroscopic observation, including cell necrosis, fatty change, hyaline degeneration, ballooning degeneration, infiltration of kupffer cells and lymphocytes (Cheedella et al., 2012).

Evaluation of hepatoprotective activity

Paracetamol induced hepatotoxicity (Gupta et al., 2004): Albino rats of wistar strain weighing 150-200 g were selected and divided into six groups of each containing six animals. Animals were treated for a period of 7 days as shown below. Paracetamol was administered to all the groups other than group I daily at a dose of (500 $\mathrm{mg} / \mathrm{kg}$ p.o.). Group III received standard drug silymarin ( $25 \mathrm{mg} / \mathrm{kg}$ p.o.) simultaneously for a period of 7 days. Whereas group IV, V and VI were treated with test extract at doses of 100, 200 and $400 \mathrm{mg} / \mathrm{kg}$ p.o. respectively. During this period of treatment the rats were maintained under normal laboratory conditions with diet and water. Treatment duration was of 7 days. All the animals were sacrificed on the $8^{\text {th }}$ day. Blood was collected by carotid bleeding under mild ether anesthesia using disposable syringes. After the blood was collected it was allowed to clot at room temperature for $30 \mathrm{~min}$. followed by centrifugation (3,000 rpm for $15 \mathrm{~min}$.) and subjected for determination of biochemical parameters. Livers of all the animals were dissected out and were placed in $10 \%$ formalin solution for histopathological study

$\mathrm{CCl}_{4}$ induced hepatotoxicity (Gupta et al., 2004): Albino rats of Wistar strain weighing 150-200 g were selected and divided into six groups of each containing six animals. Animals were treated as shown below for a 
period of 10 days. At the end of every 72 hours i.e. $4^{\text {th }}$ day, $7^{\text {th }}$ day and $10^{\text {th }}$ day $\mathrm{CCl}_{4}$ was administered at a concentration of $30 \%$ in liquid paraffin $(1 \mathrm{~mL} / \mathrm{kg}$ body weight, i.p.). Group III received standard drug silymarin $25 \mathrm{mg} / \mathrm{kg}$ p.o once in a day and $\mathrm{CCl}_{4}$ as mentioned above. Whereas group IV, V and VI were treated with test extract at a dose of (100, 200 and $400 \mathrm{mg} / \mathrm{kg}$ p.o.) respectively. During this period of treatment the rats were maintained under normal laboratory conditions with diet and water Treatment duration was of 10 days, all the animals were sacrificed after the last injection of $\mathrm{CCl}_{4}$ i.e. on $11^{\text {th }}$ day. Blood was collected by carotid bleeding under mild ether anesthesia using disposable syringes. After the blood was collected it was allowed to clot at room temperature for $30 \mathrm{~min}$, followed by centrifugation (3,000 rpm for $15 \mathrm{~min}$.) and subjected for determination of biochemical parameters. Livers were dissected out and were placed in $10 \%$ solution and subjected for histopathological study.

Estimation of serum SGPT: The blood sample was collected and pipetted into tube marked $(100 \mu \mathrm{L})$, the sample was mixed well with working ALT reagent $(1,000 \mu \mathrm{L})$ and aspirated immediately for measurement. The analyzer was programmed as per assay parameters. The analyzer was blanked with purified water. The absorbance was read after $60 \mathrm{sec}$. The reading was repeated after every $30 \mathrm{sec}$ i.e. up to $120 \mathrm{sec}$ at $340 \mathrm{~nm}$ wavelength. The mean absorbance was determined as change per min depending upon the type of analyzer and the flow-cell capacity, volume of reagent and test was adjusted accordingly. Care was taken to maintain sample to reagent ratio (Reitman and Frankel, 1957; Nkosi et al., 2005).

Estimation of serum SGOT: The blood sample was collected and pipetted into tube marked $(100 \mu \mathrm{L})$, the sample was mixed well with working AST reagent $(1,000 \mu \mathrm{L})$ and aspirated immediately for measurement The analyzer was programmed as per assay parameters. The analyzer was blanked with purified water. The absorbance was read after $60 \mathrm{sec}$. The reading was repeated after every $30 \mathrm{sec}$, i.e. up to $120 \mathrm{sec}$ at $340 \mathrm{~nm}$ wavelength. The mean absorbance was determined as change per min depending upon the type of analyzer and the flow-cell capacity, volume of reagent and test was adjusted accordingly. Care was taken to maintain sample to reagent ratio (Kind and King, 1954; Reitman and Frankel, 1957).

Estimation of serum alkaline phosphate: The blood sample was collected and pipetted into tube marked $(100 \mu \mathrm{L})$, the sample was mixed well with working ALP reagent $(1,000 \mu \mathrm{L})$ and aspirated immediately for measurement. The analyzer was programmed as per assay parameters. The analyser was blanked with purified water. The absorbance was read after $60 \mathrm{sec}$. The reading was repeated after every $30 \mathrm{sec}$ i.e. up to $120 \mathrm{sec}$ at $405 \mathrm{~nm}$ wavelength. The mean absorbance was determined as change per min depending upon the type of analyzer and the flow-cell capacity, volume of reagent and test was adjusted accordingly. Care was taken to maintain sample to reagent ratio (Reitman and Frankel, 1957; Nkosi et al., 2005).

Estimation of bilirubin (Malloy, 1937): The blood sample was collected and pipetted into tube marked (50 $\mu \mathrm{L})$, then the sample was mixed well with working reagent $(1,000 \mu \mathrm{L})$ and incubated at room temperature for 5 min. The analyser was programmed as per assay parameters and blanked with purified water. The absorbance of the sample, blank and test was measured at $546 \mathrm{~nm}\left(\lambda_{1}\right)$ and $630 \mathrm{~nm}\left(\lambda_{2}\right)$.

Estimation of total protein: Total protein estimation was done by standard method of Lowry (Lowry, 1951).

Preparation of Lowry Solution: It was prepared by mixing the following solutions i.e. solution A, solution B and solution $C$ in a ratio 100:1:1 respectively. Solution A: 2.9 $\mathrm{g} \mathrm{NaOH}$ was dissolved in $200 \mathrm{~mL}$ distilled water, then in it $14.3 \mathrm{~g} \mathrm{Na}_{2} \mathrm{CO}_{3}$ was added, the volume was made up to $500 \mathrm{~mL}$ with distilled water. Solution B: $1.4 \mathrm{~g}$ of $\mathrm{CuSO}_{4} 5 \mathrm{H}_{2} \mathrm{O}$ was dissolved in $80 \mathrm{~mL}$ distilled water and the volume was made up to $100 \mathrm{~mL}$ with distilled water. Solution C: $2.9 \mathrm{~g} \mathrm{Na}$ tartrate $2 \mathrm{H}_{2} \mathrm{O}$ was dissolved in $80 \mathrm{~mL}$ distilled water and the volume was made up to $100 \mathrm{~mL}$ with distilled water.

Preparation of Folin reagent: $5 \mathrm{~mL}$ of $2 \mathrm{~N}$ Folin Ciocalteu's Phenol reagent was mixed with $6 \mathrm{~mL}$ of distilled water. The solution being light sensitive was kept in amber colored container. The samples were taken out from freezer, vortexed well and $0.5 \mathrm{~mL}$ was transferred in 10 $\mathrm{mL}$ glass tube. Then in it $0.7 \mathrm{~mL}$ Lowry solution was added and caped well. The tubes were vortexed briefly for mixing. Then the tubes were incubated for $20 \mathrm{~min}$ at room temperature in dark. After 20 min of incubation the samples were taken out and $0.1 \mathrm{~mL}$ Folin reagent was added to each tube. The tubes were caped and vortexed for mixing. The tubes were incubated once more for $30 \mathrm{~min}$, After $30 \mathrm{~min}$ the samples were vortexed again. The samples were then transferred in a cuvette and the absorbance was measured against blank. From the standard curve of the blood sample the protein concentration was calculated.

Estimation of albumin: The blood sample was collected and pipette into tube marked $(10 \mu \mathrm{L})$ as test, Two reagents [reagent 1 and reagent 2] were prepared. The serum/plasma $(10 \mu \mathrm{L})$ was taken as standard in reagent 1 and blank as purified water $(1000 \mu \mathrm{L})$, standard reagent $2(1,000 \mu \mathrm{L})$ and test sample $(1,000 \mu \mathrm{L})$ in reagent 2 . After mixing well the tubes were incubated at $37^{\circ} \mathrm{C}$ for $5 \mathrm{~min}$. The analyzer was programmed as per assay parameters and blanked with reagent blank. Absorbance of the standard followed by the test was measured.

Statistical significance: The results of the study were expressed as mean $\pm S E M, n=6$. ANOVA was used to analyze and compare the data, followed by Dunnet's 
test for multiple comparisons.

\section{Results}

In the paracetamol induced hepatotoxicity model there was a significant increase in the levels of the liver marker enzymes compared to negative control group. Ethanolic extract significantly $(\mathrm{p}<0.01)$ decreased the level of liver enzymes in the test treated groups (100, 200 , and $400 \mathrm{mg} / \mathrm{kg}$ ). There was highly significant $(p<0.01)$ decrease in the liver enzymes in the silymarin treated group (Table I). In the extract treated group 100 $\mathrm{mg} / \mathrm{kg}$ there was no effect on ALP, ALB, TB and TP whereas there was slightly significant $(p<0.05)$, decrease in SGPT, SGOT and DB compared with the negative control group. In $200 \mathrm{mg} / \mathrm{kg}$ test treated group there was less significant decrease $(p<0.05)$ in ALP. TB, TP and moderately significant decrease $(\mathrm{p}<0.01)$, in SGPT, SGOT, ALB and DB. In $400 \mathrm{mg} / \mathrm{kg}$ test treated group there was significant decrease $(\mathrm{p}<0.01)$ in SGPT, SGOT, ALB, ALP, TB and TP. There was dose dependent response on TB and TP in the 200 and $400 \mathrm{mg} / \mathrm{kg}$ test treated groups (Table I).

In the $\mathrm{CCl}_{4}$-induced hepatotoxicity model the ethanolic extract significantly decreased the elevated enzyme levels compared to negative control group. In the extract treated group $100 \mathrm{mg} / \mathrm{kg}$ there was no effect on ALB, TB and TP whereas there was less significant

Table I

Effect of Ficus dalhousiae extract on biochemical parameters in paracetamol induced hepatotoxicity

\begin{tabular}{|c|c|c|c|c|c|c|c|}
\hline Groups & $\begin{array}{l}\text { SGPT } \\
\text { IU/L }\end{array}$ & $\begin{array}{l}\text { SGOT } \\
\mathrm{IU} / \mathrm{L}\end{array}$ & $\begin{array}{l}\text { ALP } \\
\mathrm{IU} / \mathrm{L}\end{array}$ & $\begin{array}{l}\text { ALB } \\
\mathrm{g} / \mathrm{dL}\end{array}$ & $\begin{array}{c}\mathrm{TB} \\
\mathrm{mg} / \mathrm{dL}\end{array}$ & $\begin{array}{c}\mathrm{DB} \\
\mathrm{mg} / \mathrm{dL}\end{array}$ & $\begin{array}{l}\mathrm{TP} \\
\mathrm{g} / \mathrm{dL}\end{array}$ \\
\hline $\begin{array}{l}\text { Distilled water }(5 \mathrm{~mL} / \mathrm{kg} \text {. } \\
\text { p.o) }\end{array}$ & $233.4 \pm 2.8^{b}$ & $266.2 \pm 6.2^{b}$ & $522.6 \pm 7.1^{b}$ & $4.3 \pm 0.3^{b}$ & $0.6 \pm 0.01^{b}$ & $0.6 \pm 0.01^{b}$ & $6.5 \pm 0.6^{b}$ \\
\hline Paracetamol $(500 \mathrm{mg} / \mathrm{kg})$ & $390.8 \pm 3.4$ & $406.0 \pm 4.9$ & $640.8 \pm 1.8$ & $2.2 \pm 0.2$ & $1.124 \pm 0.01$ & $0.857 \pm 0.01$ & $3.7 \pm 0.4$ \\
\hline $\begin{array}{l}\text { Paracetamol }(500 \mathrm{mg} / \\
\mathrm{kg}) \text { plus standard si- } \\
\text { lymarin }(25 \mathrm{mg} / \mathrm{kg})\end{array}$ & $129.8 \pm 3.4^{b}$ & $157.6 \pm 2.9^{b}$ & $341.4 \pm 3.6^{b}$ & $4.4 \pm 0.4^{\mathrm{b}}$ & $0.5 \pm 0.01^{b}$ & $0.3 \pm 0.01^{b}$ & $6.6 \pm 0.3^{b}$ \\
\hline $\begin{array}{l}\text { Paracetamol }(500 \mathrm{mg} / \\
\mathrm{kg}) \text { plus extract }(100 \mathrm{mg} / \\
\mathrm{kg})\end{array}$ & $375.2 \pm 3.7 \mathrm{a}$ & $399.1 \pm 5.2^{a}$ & $625.1 \pm 5.3$ & $3.3 \pm 0.5$ & $1.1 \pm 0.01$ & $0.8 \pm 0.01^{a}$ & $5.2 \pm 0.7$ \\
\hline $\begin{array}{l}\text { Paracetamol ( } 500 \mathrm{mg} / \\
\mathrm{kg}) \text { plus extract }(200 \mathrm{mg} / \\
\mathrm{kg})\end{array}$ & $298.6 \pm 4.6^{\mathrm{b}}$ & $276.4 \pm 6.3^{b}$ & $618.6 \pm 5.8^{a}$ & $4.6 \pm 0.6^{b}$ & $1.1 \pm 0.01^{a}$ & $0.7 \pm 0.01^{b}$ & $6.2 \pm 0.7 \mathrm{a}$ \\
\hline $\begin{array}{l}\text { Paracetamol }(500 \mathrm{mg} / \\
\mathrm{kg}) \text { plus extract }(400 \mathrm{mg} / \\
\mathrm{kg})\end{array}$ & $212.2 \pm 2.5^{b}$ & $171.0 \pm 6.0^{\mathrm{b}}$ & $480.7 \pm 6.1^{b}$ & $5.8 \pm 0.4^{b}$ & $0.7 \pm 0.01^{b}$ & $0.6 \pm 0.01^{b}$ & $7.7 \pm 0.4^{b}$ \\
\hline
\end{tabular}

Table II

Effect of Ficus dalhousiae extract on biochemical parameters in carbon tetrachloride-induced hepatotoxicity

\begin{tabular}{|c|c|c|c|c|c|c|c|}
\hline Groups & $\begin{array}{l}\text { SGPT } \\
\text { IU/L }\end{array}$ & $\begin{array}{l}\text { SGOT } \\
\text { IU/L }\end{array}$ & $\begin{array}{l}\text { ALP } \\
\text { IU/L }\end{array}$ & $\begin{array}{l}\text { ALB } \\
\mathrm{g} / \mathrm{dL}\end{array}$ & $\begin{array}{c}\mathrm{TB} \\
\mathrm{mg} / \mathrm{dL}\end{array}$ & $\begin{array}{c}\mathrm{DB} \\
\mathrm{mg} / \mathrm{dL}\end{array}$ & $\begin{array}{l}\mathrm{TP} \\
\mathrm{g} / \mathrm{dL}\end{array}$ \\
\hline $\begin{array}{l}\text { Distilled water }(5 \mathrm{~mL} / \mathrm{kg} \text {. } \\
\text { p.o) }\end{array}$ & $247.8 \pm 9.4^{b}$ & $367.6 \pm 9.1^{b}$ & $522.6 \pm 7.1^{b}$ & $4.2 \pm 0.4^{b}$ & $0.6 \pm 0.01^{b}$ & $0.6 \pm 0.01^{b}$ & $6.5 \pm 0.7 b$ \\
\hline $\mathrm{CCl}_{4}(1 \mathrm{~mL} / \mathrm{kg})$ & $454.4 \pm 3.2$ & $419.4 \pm 6.6$ & $603.8 \pm 1.8$ & $2.0 \pm 0.2$ & $1.2 \pm 0.0$ & $0.7 \pm 0.0$ & $3.6 \pm 0.4$ \\
\hline $\begin{array}{l}\mathrm{CCl}_{4}(1 \mathrm{~mL} / \mathrm{kg}) \text { plus } \\
\text { standard silymarin }(25 \\
\mathrm{mg} / \mathrm{kg})\end{array}$ & $147.6 \pm 3.5^{\mathrm{b}}$ & $162.9 \pm 2.8^{b}$ & $341.4 \pm 3.6^{b}$ & $4.3 \pm 0.4^{b}$ & $0.4 \pm 0.0^{b}$ & $0.4 \pm 0.01^{b}$ & $6.6 \pm 0.3^{b}$ \\
\hline $\begin{array}{l}\mathrm{CCl}_{4}(1 \mathrm{~mL} / \mathrm{kg}) \text { plus ex- } \\
\operatorname{tract}(100 \mathrm{mg} / \mathrm{kg})\end{array}$ & $430.0 \pm 5.6^{a}$ & $395.3 \pm 4.5^{\mathrm{a}}$ & $580.4 \pm 5.5^{a}$ & $3.4 \pm 0.5$ & $1.2 \pm 0.0$ & $0.6 \pm 0.02^{a}$ & $5.2 \pm 0.7$ \\
\hline $\begin{array}{l}\mathrm{CCl}_{4}(1 \mathrm{~mL} / \mathrm{kg}) \text { plus ex- } \\
\text { tract }(200 \mathrm{mg} / \mathrm{kg})\end{array}$ & $374.2 \pm 4.5^{\mathrm{b}}$ & $275.3 \pm 6.2^{b}$ & $471.3 \pm 7.7 \mathrm{~b}$ & $4.5 \pm 0.6^{b}$ & $1.0 \pm 0.0^{b}$ & $0.5 \pm 0.02^{b}$ & $6.2 \pm 0.7 b$ \\
\hline $\begin{array}{l}\mathrm{CCl}_{4}(1 \mathrm{~mL} / \mathrm{kg}) \text { plus ex- } \\
\operatorname{tract}(400 \mathrm{mg} / \mathrm{kg})\end{array}$ & $284.6 \pm 3.2^{\mathrm{b}}$ & $230.6 \pm 5.3^{b}$ & $370.7 \pm 4.4^{\mathrm{b}}$ & $5.9 \pm 0.4^{b}$ & $0.5 \pm 0.0^{b}$ & $0.4 \pm 0.02^{b}$ & $6.2 \pm 0.4^{b}$ \\
\hline
\end{tabular}




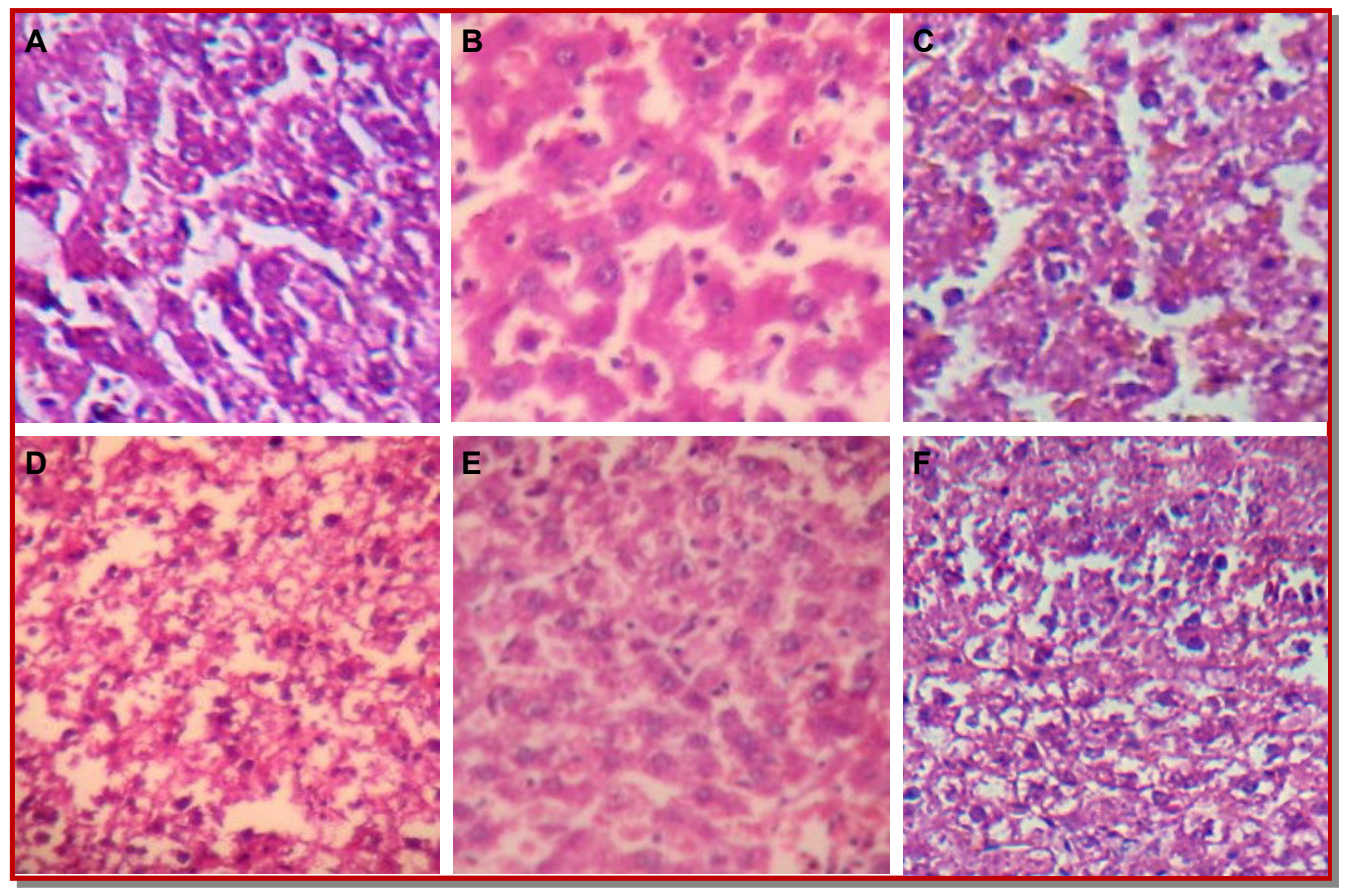

Figure 1: Histopathological changes in liver following administration of Ficus dalhousiae in paracetamol-treated rat. Control (A); paracetamol-treated (B); paracetamol and silymarin treated (C); paracetamol and extract (100 mg/ $\mathrm{kg}$ (D), $200 \mathrm{mg} / \mathrm{kg}$ (E) and 400 $\mathrm{mg} / \mathrm{kg}(\mathrm{F})$

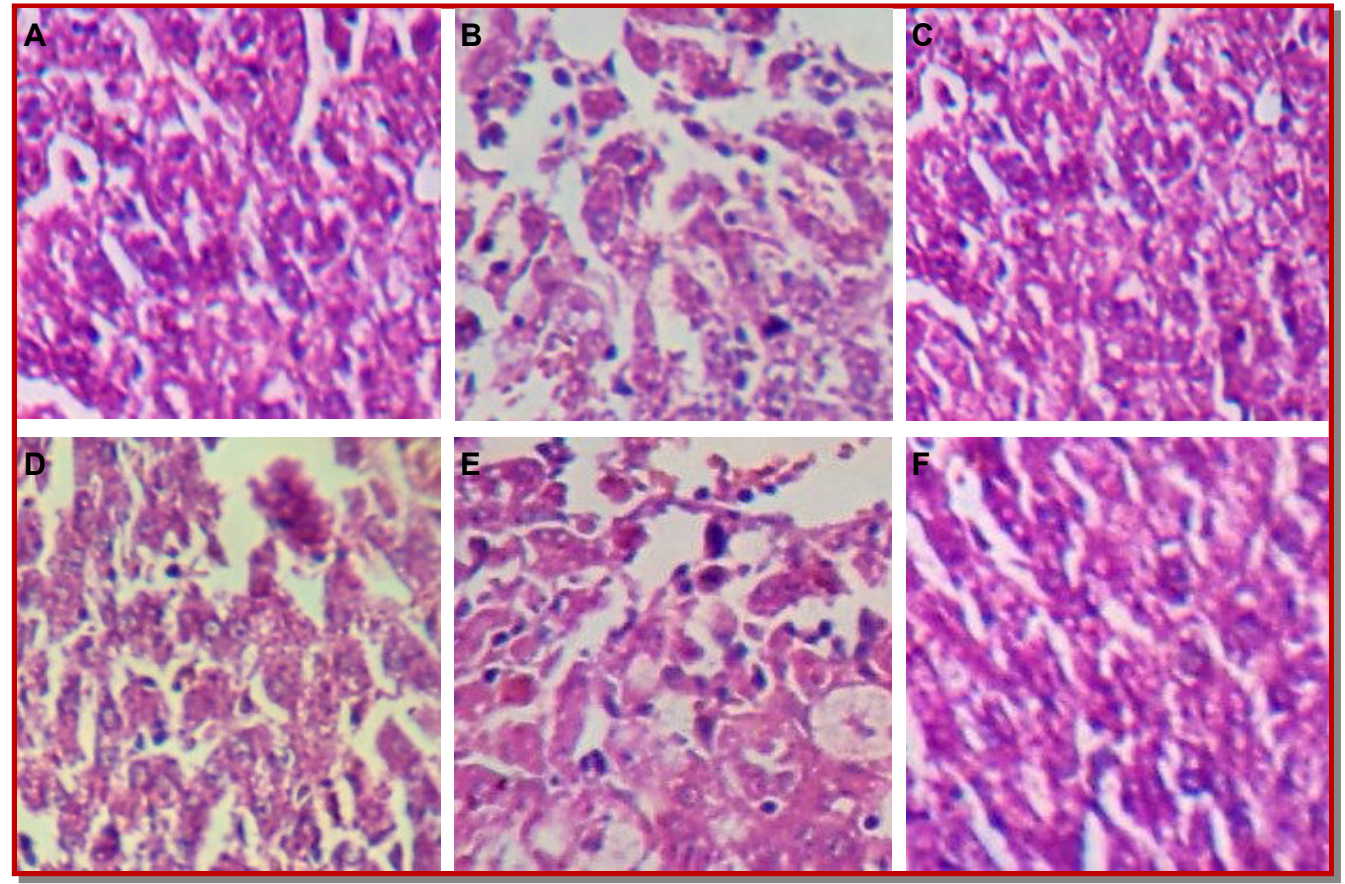

Figure 2: Histopathological changes in liver following administration of Ficus dalhousiae in carbon tetrachloride-treated rat. Control (A); $\mathrm{CCl}_{4}$-treated (B); $\mathrm{CCl}_{4}$ and silymarin treated (C); $\mathrm{CCl}_{4}$ and extract (100 mg/kg (D), $200 \mathrm{mg} / \mathrm{kg}$ (E) and $400 \mathrm{mg} / \mathrm{kg}(\mathrm{F})$

$(\mathrm{p}<0.05)$ decrease in SGPT, SGOT, ALP and DB compared with the negative control group. In 200 and $400 \mathrm{mg} / \mathrm{kg}$ test treated group there was moderately high significant decrease $(\mathrm{p}<0.01)$ in SGPT, SGOT, ALP, ALB, TB, DB and TP (Table II).
The results of the histopathological studies of both paracetamol and $\mathrm{CCl}_{4}$ intoxicated rats revealed that the negative control group showed disrupted hepatic globular architecture various degree of fatty degeneration like ballooning of hepatocytes, fatty cyst, infiltra- 
tion of lymphocytes, proliferation of kuffer cells (Figure $1 \mathrm{~B}$ and $2 \mathrm{~B}$ ) and congestion of liver sinusoids (Figure $1 \mathrm{C}$ and $1 \mathrm{C}$ ) etc. rotective effect of test extract was confirmed by histopathological examination of liver section. Administration of test extract at the dose of 100 $\mathrm{mg} / \mathrm{kg}$ (Figure 1D and 2D), $200 \mathrm{mg} / \mathrm{kg}$ (Figure 1E and 2E) and $400 \mathrm{mg} / \mathrm{kg}$ (Figure $1 \mathrm{~F}$ and $2 \mathrm{~F}$ ) showed a significant improvement of the hepatic architecture, areas of Kupper cell proliferation and sinusoid appeared normal.

\section{Discussion}

The liver can be damaged by many drugs and chemicals. In the present study paracetamol and $\mathrm{CCl}_{4}$ were selected as hepatotoxicants. In both the experimental models there was a significant increase in all the enzyme levels, SGPT, SGOT, ALP, ALB, TB and DB. Normally SGPT and SGOT are present in high concentration in liver due to hepatocyte necrosis or abnormal membrane permeability; these enzymes are released from the cells and their levels in the blood increases. ALT is a sensitive indicator of liver damage and elevation of this enzyme in nonhepatic diseases is unusual (Balamuruganvelu et al., 2014). The rise in the levels of SGPT and SGOT, ALP, ALB, TB and DB, attribute to the damaged structural integrity of the hepatic cells (Jafri and Subhani, 1999). Hepatic paranchymal cells produce pool of ALT which can be regarded as the specific enzyme for detection of liver abnormalities (Amacher, 1998; Uma et al., 2010).

Hepatocytes are the main components that regulate various metabolic activities of liver. Distortion of this organ will result in disorder of body metabolism (Zakaria et al., 2011).

In the paracetamol induced hepatotoxicity model there was a significant increase in the levels of the liver marker enzymes compared to negative control group. It is well known that necrotizing agents like paracetamol produce sufficient injury to the hepatic parenchyma to cause large increase in the bilirubin content. Control group demonstrated a normal range of AST, ALT and bilirubin levels, thus confirming that paracetamol causes liver injury at higher doses. The elevation of cytoplasmic AST and ALT is considered an indicator for the release of enzymes from disrupted liver cells. Bilirubin concentration has been used to evaluate chemically induced hepatic injury. Besides its normal functions, the liver excretes the breakdown product of hemoglobin namely bilirubin into bile (Sasidharan et al., 2010). Paracetamol intoxication is a universally established model to study the potential hepatoprotective activity of extract /compounds (Kumar et al., 2004).

$\mathrm{N}$-acetyl-p-benzoquinone imine (NAPQI) which is one of the metabolites of paracetamol after the later undergoes metabolism in the liver through the action of cytochrome $\mathrm{P}_{450}$ monooxygenase (Lee et al., 2012) is highly responsible for the toxic effects of paracetamol to liver (Farghaly and Hussein, 2010). Moreover, Somchit et al also suggested that NAPQI is involved in the formation of protein adducts through its action on DNA, proteins, cellular proteins, which in turn lead to the dysfunction and death of hepatocytes and finally liver necrosis (Somchit et al., 2005).

Liver cell injury induced by $\mathrm{CCl}_{4}$ involves the metabolism of trichloromethyl free radicals by oxidase system of endoplasmic reticulum. The secondary mechanism which link $\mathrm{CCl}_{4}$ metabolism and disturbance of hepatocytes function involves the generation of toxic products arising from $\mathrm{CCl}_{4}$ metabolism or from peroxidative degeneration of membrane lipids (Haliwell et al., 1992). From the results of the present investigation it is clearly demonstrated that various biochemical changes produced in rats by paracetamol and $\mathrm{CCl}_{4}$ were reversed by the treatment of different doses of the test extract which was supported by the histopathological reports. In the acute toxicity study as there was no mortality observed up to $2,000 \mathrm{mg} / \mathrm{kg}, 100,200,400 \mathrm{mg} / \mathrm{kg}$ dose of the extract were selected for evaluation of hepatoprotective activity. The preliminary phytochemical investigation of extract gave positive test for flavonoids and terpenoids. These chemical constituents are reported to possess a wide range pharmacological activity includeing hepatoprotective activity. In some of the cases antioxidant activity has been highlighted as a mechanism behind hepatoprotective potential of herbs (Sasidharan et al., 2010; Uma et al., 2010; Gupta et al., 2004). A recent study on leaves of $F$. dalhousiae has revealed strong antioxidant activity in DPPH, hydroxyl, nitric oxide and superoxide radical scavenging in vitro assays (Mathew et al., 2013). Therefore it is anticipated that the hepatoprotective activity of $F$. dalhousiae is due to the free radical scavenging mechanisms exhibited by the flavornoids and terpenoids present.

\section{Acknowledgement}

The authors are thankful to Dr. Md Asif Siddique Ahmed Khan, Department of Clinical Biochemistry, Shadan Institute of Medical Sciences and Research centre for providing support in the biochemical studies and histopathlologic examinations of the livers of animals and in the interpretation of the slides.

\section{References}

Akhtar MS, Asjad HMM, Bashir S, Malik A, Khalid R, Gulzar F, Irshad N. Evaluation of anti-oxidant and hepatoprotective effects of Khamira Gaozaban Ambri Jadwar Ood Saleeb Wala (KGA). Bangladesh J Pharmacol. 2013; 8: 44-48.

Alamgeer, Nawaz M, Ahmad T, Mushtaq MN, Batool A. Hepatoprotective activity of Thymus linearis against paracetamol- and carbon tetrachloride-induced hepatotoxicity in albino mice. Bangladesh J Pharmacol. 2014; 9: 230-34. 
Ali M, Qadir MI, Saleem M, Janbaz KH, Gul H, Hussain L, Ahmed B. Hepatoprotective potential of Convolvulus arvensis against paracetamol-induced hepatotoxicity. Bangladesh J Pharmacol. 2013; 8: 300-04.

Amacher DE. Serum transaminase elevations as indicators of hepatic injury following the administration of drugs. Regul Toxicol Pharmacol. 1998; 27: 119-30.

Balamuruganvelu S, Geethavani B, Premlal KR, Sengottuvelu S, Jaikumar S. Hepatoprotective activity of Polyalthia longifolia leaves against paracetamol induced hepatotoxicity in rats. Scholars J Appl Med Sci. 2014; 2: 908-10.

Bessems JGM, Vermeulen NPE. Paracetamol (acetaminophen)induced toxicity: Molecular and biochemical mechanisms, analogues and protective approaches. Crit Rev Toxicol. 2001; 31: $55-138$

Cheedella HK, Alluri R, Mohan GK. Hepatoprotective effect of ethanolic extract of Gossypium herbacium on paracetamol induced liver damage in albino rats. J Global Trends Pharmaceut Sci. 2012; 3: 772-75.

Deore SL, Khadabadi SS, Baviskar BA. Pharmacognosy and phytochemistry: A comprehensive approach. Pharma Med Press. 2014, p 481.

Farghaly HS, Hussein MA. Protective effect of curcumin against paracetamol-induced liver damage. Australian J Basic Appl Sci. 2010; 4: 4266-74.

Gupta M, Mazumder UP, Kumar TS, Gomathi P, Kumar RS. Anti-oxidant and hepatoprotective effects of Bauhinia racemosa against paracetamol- and carbon tetrachlorideinduced liver damage in rats. Iranian J Pharmacol Therapeut. 2004; 3: $12-20$

Halliwell B, Gutteridge JM, Fross CE. Free radicals, antioxidants, and human disease: Where are we now? J Lab Clin Med. 1992; 119: 598-620.

Jafri MA, Subhani MJ, Javed K, Singh S. Hepatoprotective activity of leaves of Cassia occidentalis against paracetamol and ethyl alcohol intoxication in rats. J Ethanopharmacol. 1999; 66: 355-61.

Khare CP. Indian medicinal plants an illustrated dictionary. Springer Science and Business Media, 2007, p 266.

Khandelwal KR. Practical pharmacognosy: Techniques and experiments. 2nd ed. Nirali Prakashan, 2000, pp 149-56.

Kind PRN, King EJ. Estimation of plasma phosphatase by determination of hydrolysed phenol with amino antipyrine. J Clin Pathol. 1954; 7: 322.

Kumar G, Banu, GSP, Pappa V, Sundararajan, M. Pandian MR. Hepatoprotective activity of Trianthema portulacastrum L. against paracetamol and thioacetamide intoxication in albino rats. J Ethnopharmacol. 2004; 92: 37-40.

Lee NH, Seo CS, Lee LY, Jung DY, Lee JK, Lee JA, Song KY,
Shin HK, Lee MY, Seo YB, Kim HY, Ha H. Hepatoprotective and anti-oxidative activities of Cornus officinalis against acetaminophen-induced hepatotoxicity in mice. Evid Based Complement Alternat Med. 2012; 2012: 1-8.

Lowry OH, Rosebrough NJ, Far AL, Randall RJ. Protein measurement with Folin Phenol reagent. J Biol Chem. 1951; 193: 265-75.

Mallhi TH, Abbas K, Ali M, Qadir MI, Saleem M, Khan YH. Hepatoprotective activity of methanolic extract of Malva parviflora against paracetamol-induced hepatotoxicity in mice. Bangladesh J Pharmacol. 2014; 9: 342-46.

Malloy HT, Evelyn KA. The determination of bilirubin with the photometric colorimeter. J Biol Chem. 1937; 119: 481-90.

Mathew AP, Thomas RP, Sreejith M. In vitro antioxidant activities of leaf extract of Ficus dalhousiae Miq. J Pharma Search. 2013; 8: 16-21.

Nkosi CZ, Opoku AR, Terblanche SE. Effect of pumpkin seed (Cucurbita pepo) protein isolate on the activity levels of certain plasma enzymes in $\mathrm{CCl}_{4}$-induced liver injury in rats. Phytother Res. 2005; 19: 341-45.

OECD guidelines for the testing of chemicals (acute oral toxicity -up and down procedure). Adopted 23rd March 2006.

Rao GM, Rao CV, Pushpangadan P, Shirwaikar A. Hepatoprotective effects of rubiadin, a major constituent of Rubia cordifolia Linn. J Ethnopharmacol. 2006; 103: 484-90.

Reitman S, Frankel S. In vitro determination of tranaminase activity in serum. Am J Clin Pathol. 1957; 28: 56.

Sadeque MZ, Begum ZA. Protective effect of dried fruits of Carica papaya on hepatotoxicity in rat. Bangladesh J Pharmacol. 2010; 5: 48-50.

Subramonium A, Pushpangadan P. Development of phytomedicines for liver diseases. Indian J Pharmacol. 1999; 31: 16675.

Somchit MN, Zuraini A, Bustamam AA, Somchit N, Sulaiman MR, Noratunlina R. Protective activity of turmeric (Curcuma longa) in paracetamol-induced hepatotoxicity in rats. Int J Pharmacol. 2005; 1: 252-56.

Sasidharan S, Aravindran S, Latha LY, Vijenthi R, Saravanan D, Amutha S. In vitro anti-oxidant activity and hepato-protective effects of Lentinula edodes against paracetamol-induced hepatotoxicity. Molecules 2010; 15: 4478-89.

Uma N, Fakurazi S, Hairuszah I. Moringa oleifera enhances liver anti-oxidant status via elevation of anti-oxidant enzymes activity and counteracts paracetamol-induced hepatotoxicity. Malaysian J Nutr. 2010; 16: 293-307.

Zakaria ZA, Rofiee MS, Somchit MN, Zuraini MR, Teh LK, Saleh MZ, Long K. Hepatoprotective activity of dried- and fermented-processed virgin coconut oil. Evid Based Complement Alternat Med. 2011; 2011: 1-8. 